\title{
PENGELOLAAN ADMINISTRASI MADRASAH DALAM MENINGKATKAN KUALITAS PENDIDIKAN DI MADRASAH ALIYAH NEGERI (MAN) SIDOARJO
}

\author{
Nurul Hasanah, Risma Amiliya Nur Indahsari \\ UIN Sunan Ampel, Surabaya - Indonesia I nurulhasanah982202@gmail.com
}

\begin{abstract}
Abstrak: Penelitian ini dititik beratkan pada pengelolaan administrasi madrasah yang didalmnya mencangkup hubungan antara pegawai administrasi dan kualitas madrasah, pegawai administrasi dan siswa, pegawai administrasi dan guru,dll. Tujuan dari penelitian ini adalah untuk memperoleh informasi tentang cara pengelolaan administrasi dan apa saja tugas yang harus dikerjakan oleh pegawai administrasi pada tiap-tiap administrasi. Penelitian ini merupakan penelitian deskriptif dengan menggunakan pendekatan kualitatif. Subjek penelitian ini adalah Kepala Madrasah, Para Waka, Pegawai Tata Usaha, perwakilan guru, serta komite madrasah. Hasil penelitian menunjukkan bahwa: pengelolaan administrasi untuk meningkatkan kualitas madrasah sesuai dengan prosedur, sistematis, terarah, jelas dilihat dari setiap pegawai administrasi melakukan tugasnya sesaui dengan tupoksinya masing-masing.
\end{abstract}

Keywords: pengelolaan adminisrtasi, layanan administrasi

\section{Pemdahuluan}

Administrasi pendidikan baru diperkenalkan melalui IKIP sejak tahun 1960. Disamping administrasi pendidikan sebagai ilmu, terus mengalami perkembangan sesuai dengan perkembangan pendidikan negara masing-masing. Administrasi sendiri diartikan sebagai suatu kegiatan atau usaha untuk membantu, melayani, mengatur atau mengarahkan semua kegiatan didalam mencapai suatu tujuan. Fungsi administrasi sendiri adalah perencanaan, pengorganisasian, koorninasi, komunikasi, supervisi dan evaluasi. Salah satu ruang lingkup administrasi dalam pendidikan adalah administrasi peserta didik, meliputi organisasi dan perkumpulan peserta didik, masalah kesehatan dan kesehatan peserta didik, 
penilaian dan pengukuran peserta didik, serta bimbingan dan penyuluhan bagi peserta didik.

Sehingga, administrasi pendidikan yang tertib dan teratur sangat diperlukan untuk meningkatkan kemampuian pengelolaan pendidikan bagi kepala madrasah dan guru. Peningkatan kemampuan tersebut akan berakinat positif, yaitu semakint meningkatnya efisiensi, mutu, dan perluasan pada kinerja di dunia pendidikan tersebut dan untuk memperlancar kegiatan diatas agar lebih efektif dan efisien perlu informasi yang memadai.1

Selain itu tuntutan pnguasaan teknologi informasi sudah semakin besar, sehingga setiap organisasi perlu memperhatikan peningkatan kemampuan para pegawainya dalam bidang teknologi informasi. Kondisi ini juga berlaku bagi para pegawai administras. Jika mereka tidak ingin menjadi orang-orang yang gagap atau kurang perduli teknologi. Kemampuan tentang teknologi informasi perlu terus ditingkatkan seiring perkembangannya yang semakin pesat agar kita mampu menghadapi persaingan global yang semakin ketat. Disamping itu, sarana dan prasarana pendukung untuk implemetasi teknologi informasi juga perlu disiapkan dengan baik dan selalu diperbaharui agar tidak ketinggalan jaman.

Peningkatan kemampuan pegawai administrasi dalam bidang teknologi informasi diperlukan untuk mendukung profesionalisme kerja. Selain itu, pekerjaan-pekerjaan yang terkait dengan surat menyurat, pengarsipan, inventaris barang, dan lain-lain akan lebih mudah diselesaikan dengan bantuan teknologi informasi. Tuntutan penyelesaian pekerjaan yang cepat dan tepat akan sulit dipenuhi jika menggunakan cara-cara manual, sebaik hal tersebut akan mkudah jika dibantu dengan implementasi teknologi informasi dalam bidang administrasi.

Oteng Sutisna, menyatakan bahwa administrasi pendidikan hadir dalam tiga bidang perhatian dan kepentingan, yaitu: (1) setting administrasi pendidikan (geografi, demografi, ekonomi,

${ }^{1}$ Miftah Arifin dan Aida Nahar,"Pengembangan Sistem Administrasi Sekolah berbasis teknologi informasi di MTS Darul Ulum dan MTS Mitahul Huda di kabupaten Jepara", Journal of Dedicators Community Vol. 1 No. 1 (Desember 2016), 48 
ideology, kebudayaan, dan pembangunan); (2) pendidikan (bidang garapan Administrasi); dan (3) substansi administrasi pendidikan (tugas-tugasnya, prosesnya, asas-asasnya, dan perilaku administrasi), hal ini semakin memperkuat bahwa manajemen atau administrasi pendidikan mempunyai bidang dengan cakupan luas yang saling berkaitan, sehingga pemahaman tentangnya memerlukan wawasan yang luas serta antisipatif terhadap berbagai perubahan yang terjadi di masyarakat di samping pendalaman dari segi perkembangan teori dalam hal manajemen atau administrasi. 2

Terkait dengan makna Manajemen atau Administrasi Pendidikan berikut ini akan dikemukakan beberapa pengertian manajemen pendidikan yang dikemukakan oleh para ahli. Djam'an Satori, mengemukakan bahwa administrasi pendidikan dapat diartikan sebagai keseluruhan proses kerja sama dengan memanfaatkan semua sumber personil dan materil yang tersedia dan sesuai untuk mencapaitujuan pendidikan yang telah ditetapkan secara efektif dan efesien. 3

Selain itu, menurut Made Pidarta, dalam pendidikan manajemen itu dapat diartikan sebagai aktivitas memadukan sumber-sumber pendidikan agar terpusat dalam usaha dalam mencapai tujuan pendidikan yang telah ditentukan sebelumnya.4 Sedangkan menurut Soebagio Atmodiwiro, mengemukakan bahwa manajemen pendidikan dapat didefinisikan sebagai proses perencanaan, pengorganisasian, memimpin, mengendalikan tenaga pendidik, sumber daya pendidik untuk mencapai tujuan pendidikan.

Jadi, administrasi pendidikan adalah segenap teknik dan prosedur yang digunakan dalam menyelenggarakan hubungan pendidikan sesuai dengan kebijakan yang telah ditetapkan guna mencapai tujuan pendidikan. Dalam rangka operasional konsep administrasi pendidikan tersebut, sekolah atau madrasah sebagai

${ }^{2}$ Oteng Sutisna, manajemen Pendidikan Indonesia (Bandung: Aksara, 1989), 382

${ }^{3}$ Djam'an Satori, Administrasi Pendidikan (Bandung: IKIP Bandung, 1980) 4

${ }^{4}$ Made Pidarta, Pendidikan Indonesia (Jakarta: Bina Aksara, 2008), 4 
pendidikan harus mengelola tiga hal yakni material, SDM, dan Kurikulum.

Pendidikan yang berkualitas telah menjadi tuntutan dan kebutuhan yang harus dipenuhi oleh setiap lembaga pendidikan yang tidah dapat ditawar-tawar, mulai dari tingkat dasar sampai yang pendidikan tinggi. Realisasi dari tuntutan dan kebutuhan akan kualitas tersebut harus mengacu kepada standar mutu yang telah disepakati. Dengan acuan standar tersebut akan dapat diukur dan ditentukan serta ditetapkan berkualitas tidaknya penyelenggaraan pendidikan.5

Edward Deming, sebagai salah seorang "Bapak Mutu", memberikan pengertian mutu atau kualitas sebagai "Sebuah derajat variasi yang terduga standar yang digunakan dan memiliki kebergantungan pada biaya yang rendah".6 Dijelaskan oleh Vincent, secara konvensional, kualitas mengacu pada karakteristik secara langsung suatu produk seperti performance, realibility, ease of use dan esthetics.7

Sedangkan Triana memberikan pengertian kualitas atau mutu sebagai suatu ukuran penilaian atau penghargaan yang diberikan atau dikenakan kepada barang (product) dan jasa (service) tertentu berdasarkan pertimbangan obyektif atas bobot dan kinerjanya. 8 Ukuran kualitas ini secara relatif dapat ditentukan berdasarkan kepuasan atau kebutuhan pelanggan, di samping produsen.

Dengan adanya administrasi pendidikan yang baik maka sekolah akan memiliki kualitas yang baik dalam kemajuan madrasah salah satu komponen yang di tuntut menentukan kualitas pendidikan adalah dengan melihat sejauh mana kurikulum yang

${ }^{5}$ Abd. Mukhid, "Meningkatkan Kualitas Pendidikan Melalui Sistem Pembelajaran yang Tepat, Jurnal Tadris Volume 2. Nomor 1. 2007, 132133

${ }^{6}$ Jerome S. Arcaro, Pendidikan Berbasis Mutu: Prinsip-prinsip Perumusan dan Tata Langkah Penerapan (Yogyakarta: Pustaka Pelajar, 2005), 7

7 Vinceent Gaspersz, Total Quality Management (Jakarta: Gramedia, 2005), 4

${ }^{8}$ Triana, Visionary Leadership Menuju Sekolah Efektif (Bandung: Sinar Grafika Offset, 2005), 18 
ada di sekolah berjalan dengan baik, yaitu dengan melihat sejauh mana system pembelajaran yang ada di MAN Sidoarjo dilaksanakan dengan baik. Apabila unsur-unsur yang saling terkait dan tergantung di dalamnya terlibatkan semua, baik berupa SDM, sarpras dan lingkungan, maka sistem pebelajaran tersebut dapat dikategorikan baik atau efektif. Yang secara langsung berdampak dan berkorelasi positif dalam membentuk dan meningkatkan pendidikan yang berkualitas yang ada di MAN Sidoarjo.

\section{Metodologi}

Persoalan dalam penelitian ini adalah mengenai "Pengelolaan Administrasi Madrasah Dalam Meningkatkan Kualitas Pendidikan Di Madrasah Aliyah Negeri (Man) Sidoarjo". Penelitian ini berusaha menggambarkan fenomena pada kondisi alamiah secara holistik, kompleks, dinamis dan bermakna. Pendekatan seperti ini dalam metodologi riset disebut pendekatan kualitatif atau naturalistic. 9 Jadi metode penelitian yang digunakan dalam penelitian ini adalah metode penelitian kualitatif-naturalistik, karena dilakukan dalam situasi yang wajar (natural setting). 10

Menurut Yin, penelitian yang berusaha menjawab pertanyaan tentang 'bagaimana' lebih bersifat eksplanatori dan mengarah pada penggunaan case study sebagai strateginya.11 Pendekatan kualitatif yang digunakan dalam penelitian ini adalah pendekatan rasionalitas fenomenologis.12

Melalui pendekatan kualitatif, peneliti berusaha memahami apa yang dipahami dan dipersepsikan oleh informan tentang Pengelolaan Administrasi Madrasah Dalam Meningkatkan Kualitas Pendidikan Di Madrasah Aliyah Negeri (Man) Sidoarjo. Dengan

\footnotetext{
${ }^{9}$ Lincoln \& Guba, Naturalistic Inquiry (Beverly Hill, CA: SAGE Publications, Inc., 1985).

${ }^{10}$ Bogdan dan Steven, Introduction to Qualitative Research; A

Phenomenological Approach to The Social Sciences (New York: John Wiley \& Sons Inc., 1975)

${ }^{11}$ Robert Yin, Case Study Research (London: Sage Publications, 1989).

${ }^{12}$ Noeng Muhadjir, Metodologi Penelitian Kualitatif (Yogyakarta: Rake Sarasin, 2000), 12.
} 
pendekatan kualitatif, diharapkan terungkap gambaran mengenai aktualitas, realitas sosial dan persepsi informan tanpa tercemar oleh pengukuran formal. Jika dilihat dari segi metode penguraian, penelitian ini menggunakan metode uraian deskriptif. Penggunaan metode deskripsi sebagai suatu upaya mendapatkan dan menyampaikan fakta-fakta dengan jelas dan teliti.

Deskripsi merupakan suatu uraian naratif, yaitu suatu pemaparan atas gejala-gejala yang tidak hanya untuk keperluan kejadian- kejadian itu sendiri, tetapi untuk memahami gejala yang lebih luas lagi. Sesuai dengan karakteristik yang desainnya disusun secara sirkuler, maka penelitian ini menggunakan tiga langkah, yaitu: 1. Description, 2. Reduction, 3. Selection.13

Lokasi penelitian ini adalah Madrasah Aliyah Negeri Sidoarjo. Cara yang dilakukan dalam penentuan subjek informan adalah dengan melakukan pengamatan dalam rangka memilih informan tertentu yang memungkinkan diwawancarai secara mendalam. Mengenai pemilihan dan penentuan informan, penelitian ini menggunakan teknik snowball, yaitu mengidentifikasi dan mewawancarai seseorang yang memiliki karakteristik data yang diperlukan. Mereka yang telah diidentifikasi dijadikan subjek informan guna mengidentifikasi orang-orang lain yang qualified untuk dicantumkan sebagai informan. Mereka yang telah diwawancarai diminta juga untuk menunjukkan orang lain guna dimintai informasi dan keterangan, demikian seterusnya sampai informasi yang didapatkan memiliki kredibilitas yang tinggi, dan data menunjukkan kejenuhan, artinya informasi dari informan yang satu dengan lainnya menunjukkan titik kesamaan.

Cara snowball digunakan untuk mencari informasi secara terus menerus dari informan satu ke informan lainnya, sehingga data yang diperoleh semakin banyak, lengkap dan mendalam. Penggunaan snowball dihentikan bila data yang diperoleh dianggap telah jenuh. Selanjutnya hasil atau temuan penelitian tentang supervisi akademik kepala sekolah di madrasah-madrasah kota Magetan dipadukan dalam sebuah analisis. Berdasarkan hasil

${ }^{13}$ Nasution, Metodologi Penelitian Naturalistik Kualitatif (Bandung: Transtinto, 1996). 
analisis disusunlah sebuah kerangka temuan penelitian yang bersifat kualitatif.14 Walaupun penentuan subjek informan menggunakan teknik snowball, tetapi diberikan kriteria tertentu pada informan yang dipilih.15 Subjek dan informan yang dipilih dalam penelitian ini adalah representasi langsung dari kepala sekolah, representasi dari sebagian guru, representasi dari pegawai tata usaha.

Wawancara Mendalam (Indepth Interview), yaitu pengumpulan data dengan mengajukan pertanyaan secara langsung oleh pengumpul data kepada subjek atau informan.16 Dalam penelitian ini, wawancara mendalam digunakan untuk menangkap makna secara mendasar dalam interaksi yang spesifik. Dalam menerapkan metode wawancara mendalam, penelitian ini mengikuti teori Kuntjaraningrat, yaitu wawancara kadang-kadang dilakukan berdasarkan perjanjian, atau spontan, tergantung pada waktu yang diberikan oleh informan. Untuk mempermudah proses berlangsungnya wawancara mendalam, peneliti menggunakan catatan alat perekam dengan meminta izin pada informan.

Observasi, yaitu suatu metode pengumpulan data dengan mengadakan pengamatan terhadap aktifitas, lingkungan, peristiwa, objek, lokasi penelitian secara langsung, cermat dan sistematis.17 Observasi yang dilakukan oleh peneliti adalah pengamatan tersembunyi dan pengamatan tebuka. Hal yang perlu diamati adalah kepala sekolah dalam melaksanakan tuagsnya serta kondisi Madrasah tersebut.

\footnotetext{
${ }^{14}$ Pamela Maycut \& Richard House, Beginning (Qalitative Research: A Philosophy and Practical Guide (Wasington D.C.: The Falmer Press Teachers Library, 1994).

${ }^{15}$ Ley J. Moleong, Metodologi Penelitian Kualitatif, Cet. III (Bandung: Remaja Rosda Karya, 1991), 90.

${ }^{16}$ Irawan Soehartono, Metode Penelitian Sosial (Bandung: Remaja Rosdakarya, 1999), 67.

${ }^{17}$ Suharsimi Arikunto, Prosedur Penelitian Suatu Pendekatan Praktek, Cet. XI (Jakarta: Rineka Cipta, 1998), 145.
} 
Dokumentasi, yaitu teknik pengumpulan data yang tidak langsung ditujukan kepada subjek informan.18 Dokumen yang diteliti adalah berbagai dokumen yang terkait dengan data penelitian. Data penelitian yang berasal dari dokumentasi dapat berfungsi untuk menggambarkan teori-teori yang terkait dengan permasalahan penelitian. Metode ini digunakan untuk menggali data dari sumber non-insani. Dokumen merupakan catatan peristiwa yang sudah berlalu, dokumen bisa berbentuk tulisan, gambar, foto atau karya-karya dari seseorang.

Focus Group Discussion (FGD), mengeksplorasi masalah yang spesifik, yang berkaitan dengan topik yang ibahas. Teknik ini digunakan dengan tujuan untuk menghindari pemaknaan yang salah dari peneliti terhadap masalah yang diteliti. FGD digunakan untuk menarik kesimpulan terhadap makna-makna inter- subjektif yang sulit diberi makna sendiri oleh peneliti karena dihalangi oleh dorongan subjektivitas peneliti.19

Data-data dalam penelitian ini terdiri dari data primer, sekunder dan pendukung. Data primer yang dimaksud adalah data yang diperoleh dari kajian di lapangan. Sementara data sekunder merupakan data-data yang terkait dengan hasil kajian terhadap pesantren. Sedangkan data pendukung merupakan seluruh data yang terkait dengan tema penelitian. Dengan demikian sumber data dalam penelitian ini terdiri dari insani (manusia) dan non insani (selain manusia), atau lapangan dan literatur.

Analisis data dalam penelitian kualitatif dimaksudkan sebagai proses menyusun, mengkategori data, dan mencari pola atau tema dengan maksud untuk memahami maknanya. Analisis data merupakan proses bertanya-menemukan (question-discovery). Prosedur dalam analisis data yang disarankan oleh Miles dan

\footnotetext{
${ }^{18}$ Irawan Soehartono, Metode Penelitian Sosial (Bandung: Remaja Rosdakarya, 1999), 69.

${ }^{19}$ Astridya Paramita dan Lusi Kristiana, Tecnik Focus Group Discussion dalam Penelitian Kualitatif, Buletin Penelitian Sistem Kesehatan Vol.16 No.2 (April 2013), 118.
} 
Huberman adalah: reduksi data, display data, kesimpulan sementara dan verifikasi.20

\section{Hasil dan Pembahasan}

Pengelolaan administrasi si MAN Sidoarjo sudah terkelola dengan baik. Mulai dari proses penerimaan peserta didik baru (PPDB), penyeleksian untuk PPDB ini benar-benar sudah terkelola dengan baik. Untuk penerimaan peserta didik di MAN Sidoarjo terdapat beberapa jalur salah satunya jalur tahfid. Penyeleksian peserta didik baru yang ketat ini akan membantu madrasah dalam meningkatkan kualitas yang dimiliki madrasah tersebut.

Menurut pendapat Edi Suardi bahwa tata usha madrasah adalah segala bentuk usaha untuk menacatat berbagai kegiatan dalam mencapai tujuan pendidikan di madrasah. Secara spesifik, tata usaha dapat dirumuskan sebagai segenap rangkaian kegiatan yang meliputi, menghimpun data, mencacatat data, mengolah data, menggandakan data, mengirim data, dan menyimpan keteranganketerangan untuk kepentingan pembuatan kebijakan.21

Administrasi tata usaha dalam lembaga pendidikan memiliki peran menyeluruh dari tingkat bawahan sampai atasan. Berikut kegiatan yang harus dikerjakan dalam administrasi tata usaha

- Menghimpun, yaitu kegiatan-kegiatan mencari dan mengusahakan tersedianya segala keterangan yang sebelumnya belum ada atau tersebar tanpa aturan agar siap untuk dipergunakan jika diperlukan

- Mencatat, yaitu kegiatan membubuhkan dengan berbagai peralatan tulis-menulis keterengan-keterangan yang diperlukn sehingga berwujud tulisan yang dapat dibaca, dikirim, dan disimpan. Perkembangan teknologi modern sekarang ini termassuk pula menyimpan keterangan-keterangan itu dengan alat-alat perekam suara sehingga dapat didengar, misalnya "pencatatan" pada pita rekaman.

${ }^{20}$ Miles \& Huberman, Qualitative Data Analysis (London: SAGE Publications, 1984), 20.

${ }^{21}$ Asep Sukma,Manajemen Program Ketatausahaan Madrasah,Skripsi, 3 
- Mengolah, yaitu bermacam-macam kegiatan menyajikan ketrangan-keterangan dengan maksud menyajikannya dalam bentuk yang lebih berguna.

- Mengganda, yaitu kegiatan memperbanyak dengan berbagai cara dan alat sebanyak jumlah yang diperlukan.

- Mengirim, yaitu kegiatan menyampaikan dengan berbagai cara dan alat dari satu pihak kepada pihak lain.

- Menyimpan, yaitu kegiatan menaruh dengan berbagai cara dan alat tertentu yang aman.

Untuk bagian Administrasi kurikulum di MAN Sidoarjo sudah berjalan dengan baik, terbukti dari siswa yang lulus seratus persen setiap tahunnya. Pendidikan umum yang pelaksanaannya sesuai dengan Madrasah Aliyah meliputi Bahasa Indonesia, Matematika, Olahraga, Kesenian, dll. Pendidikan agama islam sebagai ciri khas madrasah antara lain: Al-Qur'an Hadits, Sejarah Kebudayaan Islam, Fikih, Bahasa Arab, Aqidah Ahklak, dll. Selain itu juga terdapat beberapa kelas Tahfid sebagai penunjang pendidikan agama yang ada di Madrasah Aliyah Negeri Sidoarjo. Madrasah Aliyah Negeri Sidoarjo juga memiliki beberapa Ekstra Kurikuler untuk menunjang perkembangan bakat siswa sesuai dengan yag dimiliki, yaitu diantaranya:Pramuka, Hadroh, Marcing Band, Band, Badminton, Bola voly dll.

Administrasi ini juga mengatur jadwal kurikulum untuk Tahun Pelajaran yang akan dilaksanakan. Adapun tugas tersebut adalah:

- Membuat jadwal masuk madrasah dan pulang

- Membuat perencanaan kurikulum yang akan digunakan

- Membuat perencanaan pengajaran bagi guru

- Mengadakan ujian semester ujian kompetensi bagi siswa.

Menurut Purwanto, kegiatan yang dilakukan dalam administrasi kepegawaian adalah menentukan, memilih, menempatkan dan membimbing personel.22

Pada bagian administrasi kepegawaian juga terkelola dengan baik, terbukti dengan adanya guru tamatan S3 dan S2. Setiap tenaga

${ }^{22}$ Rico Novan D. A, Pelaksanaan Administrasi Kepegawaian Bidang Pengembangan Karir pada Kantor Pariwisata dan Kebudayaan Kabupaten Jember, Laporan KKN (Desembr 2014), 7 
pendidik maupun ketenaga pendidikan bekerja sesuai dengan bidang dan keahliannya masing-masing. Penanganan administrasi kepegawaian harulah mudah untuk pencariannya, misalnya:

- Pengelompokkan data guru dan pegawai

- Pengelompokkan surat-surat mutasi

- Pengelompokkan SK, dll.

Menurut Ary Gunawan administrasi srana dan prasarana pendidikan merupakan seluruh proses kegiatan yang direncanakan dan diusahakan secara sengaja dan bersungguh-sungguh serta pembinaan secara kontinu terhadarp benda-benda pendidkan agar senantiasa siap pakai dalam proses belajar mengajar sehingga PBM semakin efektif dan efisien guna membantu tercapainya tujuan pendidikan yang telah ditetapkan. Dapat disimpulkan bahwa, administrasi sarana dan prasarana pendidikan bertugas mengatur sarana dan prasarana pendidikan agar dapat memberikan kontribusi secara optimal dan berarti pada jalannya proses pendidikan. 23

Administrasi sarana dan prasarana yang ada di Madrasah Aliyah Negeri Sidoarjo juga dikelola dengan baik selain itu untuk kesuksesan proses pembelajaran untuk setiap satu tahun seklai juga diadakan penambahan peralatan-peralatan sesuai dengan kebutuhan yang ada di Madrasah Aliyah Negeri Sidoarjo.

Berkaitan dengan Administrasi Pembiayaan Madrasah Aliyah Negeri Sidoarjo mendapatkan bantuan dari masyarakat berupa infaq yang digunakan untuk proses pembangunan madrasah. Untuk saat ini Madrasah Aliyah Negeri Sidoarjo sedang melakukan pembangunan pada gedung Auditorium yang digunakan untuk menunjang kegiatan yang ada di madrasah. Sehingga madrasah dapat mengimbangi antara bertambahnya peserta didik dengan fasilitas yang ada di madrasah.

Administrasi pengelolaan laboratorium ditangani oleh guru bagian urusan laboratorium. Administrasi ini mengatur jadwal pemakaian laboratorium yang akan digunakan siswa dan

${ }^{23}$ Putri Isnaeni Kurniawati, dkk,Manajemen Sarana dan Prasarana di SMK N 1 Kasihan Bantul, Jurnal Akuntabilitas Manajemen Pendidikan, Vol 1 No. 1 (2013), 103 
mengelola administrasi yang berhubungan dengan laboratorium. Contphnya yaitu: Laboratorium komputer, laboratorium fisika, laboratorium biologi, dan laboratorium bahasa.

Menurut Sudrajad, Layanan Bimbingan dan Konseling merupakan kegiatan yang terencana berdasarkan pengukuran kebutuhan (need assessment) yang diwujudkan dalam bentuk program bimbingan dan konseling. Program bimbingan dan konseling disekolah dapat disusun secara makro untuk 3 tahun, meso 1 tahun dan mikro sebagai kegiatan operasional dan menfasilitasi kebutuhan-kebutuhan khusus. Program menjadi landasan yang jelas terukur layanan professional yang diberikan oleh konselor di sekolah.24

Pengelolaan administrasi layanan khusus pendidikan di MAN Sidoarjo yaitu Bimbingan Konseling atau bimbingan penyuluhan. Untuk membantu peserta didik dan menyikapi permasalahan yang mereka hadapi, maka Madrasah Aliyah Negeri Sidoarjo memberikan pelayanan Bimbingan Konseling. Proses pelayanan Bimbingan Konseling di Madrasah Aliyah Negeri Sidoarjo di buka setiap hari. Pelayanan ini di tujukan bagi siswa yang ingin berkonsultasi mengenai permasalahan yang sedang dihadapi. Sehingga siswa dapat mengatasi permasalahan yang sedang merekadihadapi dengan tepat karena telah dibantu oleh guru Bimbingan Konseling.

Selain itu pemberian materi dan motivasi belajar serta pengembangan jiwa peserta didik diberikan secara klasikal di dalam kelas dengan waktu yang telah ditentukan atau sesuai dengan jadwal yang ada di madrasah.untuk kegiatan lain guru Bimbingan Konseling Madrasah Aliyah Negeri Sidoarjo memiliki kegiatan khusus bagi siswa madrasah. Kegiatan program ini berupa membaca Al-Quran, waktu yang diberikan pada saat jam istirahat berlangsung. Sehingga kegiatan ini tidak mengganggu proses belajar mengajar. Kegiatan ini dilakukan selama 30 hari. Dengan adanya kegiatan ini diharapkan siswa dapat lebih sering untuk membaca Al-Quran.

${ }^{24}$ Budi Hartiningsih, Layanan Bimbingan Konseling Terhadap Kenakalan Siswa, (Tesis, 2010), 6 
Untuk menunjang proses belajar mengajar lainnya, Madrasah Aliyah Negeri Sidoarjo telah mengelolaan Administrasi Perpustakaan dengan baik. Sehingga siswa Madrasah Aliyah Negeri Sidoarjo dapat mencari materi-materi yang dibutuhkan di Perpustakaan yang ada di sekolah. Di Perpustakaan ini juga telah memiliki banyak referensi-referensi yang berkaitan dengan pelajaran yang ada di madrasah.

Untuk itu siswa tidak lagi kesulitan dalam mencari materimateri yang belum terdapat di dalam buku ajar yang telah dimiliki. Terdapat bermacam-macam buku yang bisa di baca di perpustakaan Madrasah Aliyah Negeri Sidoarjo, antara lain: buku referensi, buku fiksi dan non fiksi majalah, Koran dan lain sebagainya.

\section{Kesimpulan}

Berdasarkan uraian sebagaimana tersebut di atas, maka dapat ditarik beberapa kesimpulan sebagai berikut. Pengelolaan administasi di MAN Sidorajo sudah terkelola dengan baik, para pegawai administrasi telah melaksanakan tugas yang telah dibebankan dengan baik sesuai dengan tupoksinya masing-masing.

Administrasi tata usaha dalam lembaga pendidikan memiliki peran, yaitu menghimpun, mencatat, mengolah, mengganda, mengirim, dan menyimpan semua yang berkaitan dengan administrasi tata usaha. Administrasi kurikulum sudah terkelola dengan baik. Seperti mengenai pembuatan perencanaan kurikulum, pengajaran guru, dan lain-laim.

Administrasi kepegawaian menangani tentang pengelompokkan data guru, mengurusi tentang surat-surat mutase. Administrasi sarana dan prasarana menangani tentang peralatan dan perlengkapan yang diperlukan oleh madrasah. Dengan cara mendata semua keperluannya setelah itu jika perlengkapan tersebut segera diperlukan maka perlengkapan tersebut, jika tidak segera diperlukan maka akan diadakan satu tahun sekali.

Administrasi keunagan menangani tentang pembayaran dan bantuan-bantuan yang datang dari dalam maupun luar madrasah. 
Administrasi laboratorium ditangani oleh guru yang telah ditugaskan sehingga untuk pemakaian laboratorium harus berdasarkan izin dari petugas.

Aadministrasi bimbingan dan konseling, pelayanan ini di tujukan bagi siswa seperti, yang ingin berkonsultasi mengenai permasalahan yang sedang dihadapi, dan juga menangani urusanurusan yang lain.

Administrasi perpustkaan, menangani tentang peminjaman, kunjungan, pendataan buku, dll. Di perpustakaan ini juga telah memiliki banyak referensi-referensi yang berkaitan dengan pelajaran yang ada di madrasah. Untuk itu siswa tidak lagi kesulitan dalam mencari materi-materi yang belum terdapat di dalam buku ajar yang telah dimiliki.

Berdasarkan kesimpulan diatas, beberapa saran untuk meningkatkan lagi kinerja dari setiap pegawai administrasi dapat dirangkum sebagai berikut. Untuk mengembangkan komptensi pegawai administrasi sebaiknya madrasah mengadakan pelatihan mengenai materi tentang sistem informasi atau yang lainnya secara berkala. Jika teknologi informasi sudah berjalan efektif dan efisien, maka madrasah dapat meninjau kembali jumlah tenaga administrasi yang dibutuhkan oleh madrasah.

\section{References}

Gaspersz, Vinceent, Total Quality Management (Jakarta: Gramedia, 2005)

Arcaro , Jerome S., Pendidikan Berbasis Mutu: Prinsip-prinsip Perumusan dan Tata Langkah Penerapan (Yogyakarta: Pustaka Pelajar, 2005)

Arifin, Miftah dan Aida Nahar,"Pengembangan Sistem Administrasi Sekolah berbasis teknologi informasi di MTS Darul Ulum dan MTS Mitahul Huda di kabupaten Jepara", Journal of Dedicators Community Vol. 1 No. 1 (Desember 2016) 
Arikunto, Suharsimi, Prosedur Penelitian Suatu Pendekatan Praktek, Cet. XI. Jakarta: Rineka Cipta.1998

Bogdan dan Steven, Introduction to Qualitative Research; A Phenomenological Approach to The Social Sciences. New York: John Wiley \& Sons Inc.1975

Hartiningsih, Budi, Layanan Bimbingan Konseling Terhadap Kenakalan Siswa, (Tesis, 2010)

Maycut, Pamela \& Richard House, Beginning (Qalitative Research: A Philosophy and Practical Guide. Wasington D.C.: The Falmer Press Teachers Library.1994

Miles \& Huberman, Qualitative Data Analysis. London: SAGE Publications.1984

Moleong, Ley J., Metodologi Penelitian Kualitatif, Cet. III. Bandung: Remaja Rosda Karya.1991

Muhadjir,Noeng, Metodologi Penelitian Kualitatif. Yogyakarta: Rake Sarasin. 2000

Mukhid, Abd. Mukhid, “Meningkatkan Kualitas Pendidikan Melalui Sistem Pembelajaran yang Tepat, Jurnal Tadris Volume 2. Nomor 1. 2007

Nasution, Metodologi Penelitian Naturalistik Kualitatif. Bandung: Transtinto, 1996

Paramita,Astridya dan Lusi Kristiana, Tecnik Focus Group Discussion dalam Penelitian Kualitatif, Buletin Penelitian Sistem Kesehatan Vol.16 No.2.(April 2013)

Pidarta,Made.Pendidikan Indonesia.Jakarta: Bina Aksara.2008

Lincoln \& Guba, Naturalistic Inquiry. Beverly Hill, CA: SAGE Publications, Inc.1985

Satori,Djam'an.Administrasi Pendidikan.Bandung: IKIP Bandung.1980

Soehartono, Irawan. Metode Penelitian Sosial. Bandung: Remaja Rosdakarya.1999 
Sutisna,Oteng.Manajemen Pendidikan Indonesia.Bandung: Aksara.1989

Triana, Visionary Leadership Menuju Sekolah Efektif (Bandung: Sinar Grafika Offset, 2005)

Yin,Robert, Case Study Research. London: Sage Publications.1989

Sukma,Asep.Manajemen Program Ketatausahaan Madrasah.Skripsi

Kurniawati,Putri Isnaeni dkk.Manajemen Sarana dan Prasarana di SMK N 1 Kasihan Bantul, Jurnal Akuntabilitas Manajemen Pendidikan. Vol 1 No. 1 (2013)

Novan D. A.Rico Pelaksanaan Administrasi Kepegawaian Bidang Pengembangan Karir pada Kantor Pariwisata dan Kebudayaan Kabupaten Jember, Laporan KKN.(Desembr 2014) 